\title{
EI Naturalismo radical: Eduardo López Bago. Un texto desconocido de Alejandro Sawa
}

\author{
Miguel ANGel LozANo MARCo
}

Universidad de Alicante

En enero de 1904 el bohemio Alejandro Sawa hace referencia de manera muy sucinta, desde las páginas de Alma Española, a su época de militancia naturalista: «En poco más de dos años publiqué, atropelladamente, seis libros, de entre los que recuerdo, sin mortales remordimientos: Crimen legal, Noche, Declaración de un vencido y La mujer de todo el mundo ${ }^{1}$. Por aquellas fechas, Rafael Cansinos-Assens, joven aprendiz de literato con obstinada voluntad de ser modernista, acude a conocer al gran bohemio y nos deja narrado su primer encuentro con él. Un párrafo de la conversación que mantuvieron tiene para nuestro tema evidente interés, $y$ modifica en cierto modo lo afirmado en la nota autobiográfica:

1 «Juventud triunfante. Autobiografías. Alejandro Sawa», en Alma Española, 3 de enero de 1904, pp. 10-11. Este texto fue reproducido luego en Iluminaciones en la sombra, Madrid, Biblioteca Renacimiento, 1910; puede leerse en la excelente edición anotada por Iris M. Zavala, Madrid, Ed. Alhambra, 1977. 
Hay que renovarse o morir, según el lema d'annunziano... Ya ve usted, yo también he cambiado... En mi primera época hacía novelas truculentas, de un realismo zolesco exagerado, por el estilo de Zahonero, el de La Carna$z a$, y Ubaldo Romero de Quiñones, el del Lobumano, cosas de que hoy me avergüenzo... Pero ¿no escribió también Hugo el Bug-Jargal y no empezó Balzac imitando a Paul de Kock?... Esas cosas esperpénticas de sátira social me valieron el destierro en París, condenado por delito de imprenta, y merecían desde luego el castigo por delito de lesa literatura... Si algún día encuentra en los baratillos un ejemplar de la La mujer de todo el mundo, le ruego no lo lea... Ese Sawa no es el Sawa de hoy... Los jueces que me desterraron me hicieron un favor..., porque fue en París donde verdaderamente nací al arte, apadrinado por Hugo, por Gautier, por Dumas y el divino Verlaine... Hoy debe usted leerme en Alma Española y en Los Lunes, donde me brindan colaboración... Por esas producciones nuevas me conocen los poetas jóvenes, que ven en mí a un hermano mayor... ${ }^{2}$.

Si en la primera cita confesaba que no sentía «mortales remordimientos» por haber escrito esas novelas, aquí afirma rotundamente que se avergüenza de ellas. Esta conversación tendría lugar en una fecha muy cercana a la de la aparición de esa "Autobiografía», ya que pertenece a la época de Alma Española, donde colaboró desde diciembre de 1903 hasta su último número, en abril de $1904^{3}$. Nos llama la atención, sobre todo, que vincule su obra naturalista con la de Zahonero y la de Ubaldo Romero de Quiñones, escritor este último que no aparece mencionado en ninguno de los estudios sobre el naturalismo más o menos recientes ${ }^{4}$, y que no cite el nombre del que fue no sólo el más conocido

2 Rafael Cansinos-Assens, «Alejandro Sawa, el gran bohemio», Indice, XV, n. 149 (mayo, 1961), pp. 22-23. El texto vuelve a aparecer en el primer volumen de sus memorias, La novela de un literato, 1, Madrid, Alianza Editorial, 1982, p. 71. Este mismo escritor sitúa así a Sawa en el panorama literario : «Simbolistas, parnasianos y decadentes les han enviado (de París), con Alejandro Sawa, un nuncio extraordinario. Lo que Ganivet ha sido para la generación del 98 , lo ha sido A. S. para los jóvenes del 900 . Ya no se piensa en Taine ni en Montaigne, sino en Verlaine y Mallarmé» (Las Escuelas Literarias, Madrid, 1916, p. 274, cit. por J. Cejador y Frauca, Historia de la lengua y la literatura castellana, t. IX, Madrid; Gredos, 1973, p. 433). Martínez Ruiz, en su Charivari, opina: «Sawa quiere ser aqui una especie de Moréas» (Azorín, Obras completas, I, Madrid, Aguilar, 1975, p. 147). El destierro que menciona parece ser, con seguridad, una pura invención del bohemio. Allen Phillips, en su fundamental estudio Alejandro Sawa, mito y realidad, Madrid, Eds. Turner, 1976, p. 65, afirma: «Yo creo que fue a París sencillamente por tratarse de París y para realizar el sueño de tantos adolescentes, y no por un delito de imprenta como se ha dicho alguna vez.»

3 A. Sawa colaboró con nueve artículos en Alma Española, siendo el primero «Canalejas y la Academia", publicado el 20 de diciembre de 1903; el último apareció en el último número de la revista, el 30 de abril de 1904: se titulaba «Jornada histórica». Cinco de ellos se encuentran recogidos en el apéndice de la ed. de Iluminaciones preparada por Iris M. Zavala, cit.

4 La Carnaza fue publicada en 1884. Datos sobre Romero Quiñones encontramos en Juan Ignacio Ferreras, Catálogo de novelas y novelistas españoles del siglo 
naturalista, merced a los escándalos que suscitaron sus novelas, sino también su maestro y modelo en esas lides: Eduardo López Bago. Tampoco aparecerá mencionado en ninguno de los escritos de Sawa posteriores a su regreso de París, en 1896, quedando, por tanto, excluido de ese desfile de escritores que discurre por las páginas de su obra maestra, Iluminaciones en la sombras ${ }^{5}$.

Ahora bien, si fue eliminado de su personal «iconografía» modernista, la actitud de Sawa ante el escandaloso escritor fue muy otra antes de su decisivo viaje a París, hacia 1890, y buena prueba de ello es el texto que aquí rescatamos. La razón principal de que haya permanecido oculto para los críticos que se han venido ocupando de recuperar y estudiar la obra del escritor bohemio es muy clara: su lugar de aparición. «Impresiones de un lector. Eduardo López Bago» fue publicado como apéndice de El Cura, novela difícil de encontrar, y está situado a continuación de otro apéndice, redactado por el autor de la novela, de notable importancia para entender el sentido de su concepción del naturalismo ${ }^{6}$. El Cura aparecería hacia 1885 o, todo lo más, principios de 1886, pues Sawa dedica la parte final de su trabajo al comentario de la trilogía de La Prostituta, considerándola como un conjunto cerrado; las tres novelas, por los datos que encontramos en los apéndices que acompañan a todas ellas, fueron publicadas con cierta inmediatez: $L a$ Prostituta y La Pálida vieron la luz con menos de tres meses de diferen-

$X I X$, Madrid, Cátedra, 1979: lo califica de autor «rigurosamente olvidado» pero de copiosa producción; además de novelas publicó libros de sociología y sobre temas diversos; opina que sus novelas «pueden ponerse en relación estrecha con López Bago». El loburmano [sic]. Novela sociológica original fue publicada en Madrid en 1894.

5 López Bago fue procesado por tres de sus novelas: La Prostituta, La Pálida y El Cura, y según confesión propia, sus libros se vendían abundantemente. Era mayor que Sawa, pues nació en 1855 -el autor de Iluminaciones vio la primera luz en Sevilla en 1862- y, según Federico Carlos Sainz de Robles, estudió Medicina en Madrid (Ensayo de un Diccionario de Literatura, t. II, Madrid, Aguilar, 1964³, art. «López Bago»). Luis López Jiménez, en su libro El naturalismo y España, Madrid, Alhambra, 1977, lo califica de «extravagante y anticlerical médico», autor de novelas «de un Naturalismo degradado» (p. 24). Es muy posible que al regreso de Sawa, en 1896, López Bago haya marchado ya a América (J. I. Ferreras fecha este viaje hacia 1890 mientras que Cejador lo retrasa hasta hacia 1900: $O p$. cit., p. 235), y alli publica El separatista, La Habana, s. f., pero parece ser de 1895, y Carne importada, Buenos Aires, s. f. Pío Baroja, que dice oyó hablar con escándalo de López Bago en Pamplona, en los juveniles años, cuando habitaba en esa ciudad con su familia, nos informa que lo vio en 1915 ó 1916 «en la redacción del periódico España» (Obras Completas, VII, Familia, infancia y juventud, Madrid, Biblioteca Nueva, 1949, p. 567). Murió en Alicante, en octubre de 1931.

6 El Cura (Caso de incesto). Novela médico-social, Madrid, Juan Muñoz y Compañía, Editores, s. f. El Apéndice de López Bago, titulado «Vosotros y yo», ocupa las pp. 259-292, y el de Alejandro Sawa las pp. 295-309. 
cia, puesto que aquélla fue denunciada por el Gobernador civil de Madrid el 17 de octubre de 1884 -suponemos que poco después de hacer su aparición en las librerías - y la segunda fue denunciada en enero de 1885. Unos meses más tarde sería publicada La Buscona, ya que en su apéndice, al traducir López Bago un texto teórico de Zola, apunta: «Ignoraba seguramente el Sr. Zola, cuando escribió lo anteriormente leído, que para mayor demostracción de sus asertos publicados el año de 1881 , en España tendría yo que traducir sus opiniones, para que con ellas se defendiera en el año de 1885 un escritor naturalista, contra el cual se han intentado todo género de persecuciones» ${ }^{7}$. Observando la rapidez con que se van sucediendo estas novelas, debemos suponer la fecha mencionada para El Cura. En el apéndice de esta obra su autor nos dice: «A El Cura seguirán El Confesonario y La Monja, así como a La Prostituta siguieron La Pálida y La Buscona» ${ }^{8}$; y en el apéndice de esta última informa que con ella termina «el análisis de una llaga social, estudiada por la experimentación propia de la escuela naturalista» ${ }^{9}$. Resulta obvio que no había pensado aún escribir la cuarta novela en la que, con la muerte del protagonista, el joven Miguel Loitia, cierra el ciclo: no sabemos, pues, si La Querida ${ }^{10}$ sería redactada con posterioridad a las obras que componen la trilogía anticlerical o simultáneamente a éstas. De todos modos, lo que resulta claro es que Alejandro Sawa escribió este texto a propósito de lo que, hasta ese momento, era una trilogía que se consideraba concluida, y que desconocía la novela a la que sus «Impresiones de un lector» iban a servir de segundo apéndice.

7 Todas las novelas que aquí comentamos aparecieron en Madrid, Juan Muñoz y Compañía, Editores, y no llevan fecha de publicación. En los apéndices, Eduardo López Bago suele publicar traducciones, hechas por él mismo, de textos teóricos de Zola: serian, pues, las primeras que aparecen en España, ya que preceden en algunos años a las citadas por W. T. Pattison. Aclara el novelista la finalidad que persigue con ello: «Conviene mucho que las opiniones de monsieur Zola se conozcan en España, y se discutan aquí donde tanto se discute el naturalismo, y sin embargo no se discute, como se ha discutido en Francia, seriamente». (Apéndice a La Pálida, p. 278).

8 Op. cit., p. 262. Las otras dos novelas de la trilogía anticlerical también vieron la luz en la editorial mencionada, sin hacer constar la fecha de publicación: El Confesonario. Satiriasis. Segunda parte de El Cura, y La Monja. Tercera parte de El Cura.

9 «La moral del naturalismo», apéndice de La Buscona, p. 243. Traduce aquí, con algunas supresiones, el texto de Zola «De la moralidad en la literatura», y reproduce al final unas opiniones de Zahonero.

10 La Querida lleva en su portada, entre paréntesis, la aclaración: «Cuarta y última parte de La Prostituta». Contiene también un retrato del autor hecho por Nicolás Megía. 
En 1886, en una fecha que no debe de estar muy alejada de la de publicación de El Cura, apareció Crimen legal, la segunda novela de Sawa, acompañada por un apéndice de López Bago titulado «Análisis de la novela» (no podemos saber, por ahora, cuál de los dos apéndices tiene prioridad) ${ }^{11}$. En él, el autor de La Prostituta le da la bienvenida a la barricada del naturalismo, le elogia los conocimientos médicos adquiridos, necesarios para abordar el asunto, y lo acertado de su elección: un caso de distocia, con lo que se plantea un enfrentamiento entre la ciencia y lo que la Iglesia católica prescribe en esos casos. Pero al mismo tiempo censura en el autor cierta proclividad hacia el romanticismo que no es de su agrado, y excluye del campo naturalista su anterior novela, La mujer de todo el mundo. Luis S. Granjel, que subraya el magisterio de López Bago sobre Sawa ${ }^{12}$, explica también, apelando a su raíz romántica, las razones de la divergencia y su posterior evolución:

No cabe dudar que en el temperamento de Alejandro Sawa y en su temprana preferencia por la ideología romántica, influencias ambas patentes en su estilo literario, halla justificación el hecho evidente de que la adscripción suya al naturalismo propugnado por López Bago nunca llegó a ser total; ello, y también inclinaciones inspiradas por sus primeras admiraciones de lector adolescente (Espronceda, Bécquer y Lamartine, Musset, Byron y Víctor Hugo), explican el que con ocasión de su estancia en París, Alejandro Sawa olvidara su fe en el naturalismo y se adhiriera al credo poético de Verlaine ${ }^{13}$.

El crítico Andrés González Blanco, al igual que bastantes años después hará Walter T. Pattisson ${ }^{14}$, une sistemáticamente los nombres de V. Hugo y Zola al hablar del naturalismo de Sawa ${ }^{15}$; y Allen Phillips, en su fundamental estudio, define el carácter de su novelística: «Las novelas de Sawa son, pues, híbridas. Es decir, hay en ellas un fuerte residuo romántico debido quizá en parte a su temperamento an-

11 Iris M. Zavala en el excelente estudio introductorio a su ed. de Iluminaciones señala la importancia de este texto; a él alude repetidamente, y reproduce abundantes fragmentos, Allen Phillips en su fundamental libro cit., esp. pp. 186-193.

12 Vide sus estudios «Alejandro Sawa», en Maestros y amigos de la Generación del Noventa y Ocho, Salamanca, 1981, pp. 145-163; Eduardo Zamacois y la novela corta, Salamanca, 1980, esp. p. 32, así como su libro La Generación Literaria del 98, Salamanca, Anaya, 1973, p. 118.

13 Luis S. Granjel, «Alejandro Sawa», p. 150.

14 El naturalismo español, Madrid, Gredos, 1969. En pp. 135-139 caracteriza el tipo de naturalismo de López Bago y Sawa como «una rendición completa al naturalismo de Zola mezclado con humanitarismo sentimental al estilo de Los miserables o Los misterios de París».

15 Andrés González Blanco, Historia de la novela en España desde el Romanticismo a nuestros dias, Madrid, Sáenz de Jubera, Hermanos, Editores, 1909; vide esp. pp. 701 y 870 . 
daluz, en consonancia con una tendencia natural hacia la exageración o la exaltación. Los argumentos folletinescos y melodramáticos revelan también sus antecedentes; un lenguaje con frecuencia declamatorio revela también esa filiación» ${ }^{16}$.

Creo acertado y digno de ser tenido en cuenta el término empleado por Sawa para definr el tipo de naturalismo del que López Bago es el máximo representante: naturalismo radical; con ello hace referencia a una postura extrema y combativa de la que es cabal expresión el apéndice que el escritor redacta para su novela El Cura, erigiéndose en el cabecilla de la insurrección que da al naturalismo su auténtico significado:

El naturalismo había ido en España a los ateneos antes de tiempo, y no se encontraba cómodo en las posturas académicas a que en algunos libros lo condenan a mostrarse escritores que deben ser tachados como eclécticos en este punto; necesario fue sacarlo de los cómodos sillones de terciopelo, desencadenarlo de las atildadas plumas que lo sujetaban y hacer que recuperase su verdadero carácter revolucionario. Para crecer tiene que luchar en las calles, ganar primero la opinión del pueblo, ser un héroe popular; su sitio no es la academia todavía. Es algo mejor que esto. La barricada. Y a la barricada fue conmigo, y en ella sigue hasta obtener el triunfo ${ }^{17}$.

Se enfrenta, a continuación, con los románticos e idealistas, con los autores de la que denomina "novela bonita», y centra en dos nombres su crítica: Alarcón y Valera. Al contrario de lo que sucede en sus propias obras, el autor de El Escándalo y La Pródiga «no presenta el vicio repugnante, no, sino amable en sumo grado; lo viste de raso, lo rocía de perfumes, lo rodea de riquezas...». Interpreta la denuncia gubernativa que recayó sobre La Prostituta y la posterior sentencia del Tribunal Supremo (después de «casi un año de vía crucis») que decretaba la libre absolución, como el acoso del que salió triunfante el naturalismo en España: «El naturalismo no puede ser una literatura prohibida.» Califica a sus enemigos literarios, Alarcón y Valera, de aficionados a la literatura y profesionales de la política, y frente a ellos se dignifica en un enfático «nosotros, los escritores de profesión»; luego nos enteramos que en ese nosotros López Bago forma grupo con Galdós, Alas y Sellés. Concluye el apéndice con una profesión de fe, una exposición de los procedimientos empleados y una nueva y agresiva denuncia: «El naturalismo no es una secta, es una verdad», afirma, creyendo

16 Op. cit., p. 187.

17 «Vosotros y yo», apéndice a El Cura, pp. 262-263. En la transcripción de los textos, incluyendo el de Sawa, modifíco sólo la acentuación, adecuándola a las normas y usos actuales. 
en la inmortalidad de un arte aliado con la ciencia; es una literatura «científica» porque pretende analizar el determinismo de los fenómenos sociales y humanos mediante la observación y el experimento; y todo ello exaspera los ánimos de ilustres académicos:

¡Cómo! dicen los durmientes de la Academia. ¿Quién es ese que se atreve a escribir una novela usando palabras que antes sólo se empleaban en los libros de patología? ¿Qué novelistas son estos que, al hablar de una mujer, nos describen el parto, cuando la gran ventaja que tenían las heroínas de nuestros libros era precisamente el no parir nunca? ¿Qué literatura es la que no aspira a ponerse nuestro uniforme de inmortales, y anda por los anfiteatros estudiando la miseria humana, vistiendo la blusa de disección, la horrible blusa negra con ribetes amarillos? ¿Qué falta hace eso? La humanidad bien vestida es la que debe retratarse; el desnudo, ¿para qué? ${ }^{18}$.

Mercedes Etreros, en un excelente estudio que es imprescindible citar en este lugar ${ }^{19}$, agrupa las novelas de López Bago, Sawa y Zahonero bajo el epígrafe de «naturalismo erótico». Personalmente encuentro más acertada la denominación apuntada por Sawa en el texto que transcribo, pero no niego que la calificación de Etreros tenga mucha parte de razón: si bien la temática sexual es la predominante en estos novelistas, no es la única; $y$, por otra parte, convendría, desde el mismo término empleado, señalar la diferencia existente entre la peculiar concepción de la vida sexual que aparece en estos autores y la visión regeneradora y vitalizadora del erotismo que unos años después encontraremos en Zamacois, Trigo y otros varios novelistas. En estas novelas de la década de los ochenta (como tan exactamente estudia Mercedes Etreros) el sexo está contemplado en sus aspectos más sórdidos y degradados: es el sexo prostituido, con sus secuela de bajezas morales y enfermedades venéreas. Se tiende a presentar, de manera obsesiva, lo más repugnante y sombrío, acumulando miserias y lacras. Según esta escritora, los novelistas mencionados «siguen la fórmula zoliana en el sentido más estricto», pero la aplican sólo a ciertos aspectos del naturalismo: exaltan la ciencia experimental, defienden el determinismo positivista y tienden siempre en sus descripciones a presentar «no lo real, sino el feísmo que caracteriza al entorno en que se desarrolla la acción»; el narrador se aleja con frecuencia del impersonalismo naturalista y los relatos adquieren un evidente carácter tendencioso.

Las dos primeras novelas de la tetralogía de López Bago, La Prostituta y La Pálida, responden plenamente a esta caracterización. Todo

18 Ibid., p. 290.

19 «El naturalismo español en la década de 1881-1891», en el libro Estudios sobre la novela española del siglo XIX, Madrid, C. S. I. C., 1977, pp. 49-131. 
es sombrío; se potencia lo repugnante; los seres encanallados triunfan, mientras que los pocos personajes bondadosos son unas víctimas destinadas a perecer; el determinismo fisiológico y del medio es implacable; y, sobre todo ello, en los argumentos predomina lo efectista y desmesurado: los cuarenta burdeles, secreta propiedad del marqués de Villaperdida, forzados al máximo rendimiento para enviar las ganancias íntegras al Vaticano; los contagios de la repugnante enfermedad venérea que sufre el devoto marqués a su esposa, de cuyas consecuencias fallece, y posteriormente a su único hijo por medio de la «Pálida», una pobre muchacha que acude al burdel después de sufrir un brutal intento de incesto por parte de su padre, alcohólico impenitente. En la segunda novela no son menos espectaculares las reuniones y orgías de «La Botica», una asociación de viciosos - pertenecientes a las mejores familias del país - desahuciados por la ciencia médica, que se enardecen con su grito ritual: «iViva la muerte!» (no está de más recordar a propósito de todo ello que, como apuntan Pattison e Iris M. Zavala, este tipo de naturalismo recoge también la herencia de la novela de folletín, de los relatos de «misterios...») ${ }^{20}$. Frente a todo esto se levanta la figura del médico, el doctor Pérez, «jovial materialista» que lee su breviario - Claude Bernard-y dice conocer el cuerpo humano «lo mismo que si lo hubiera hecho en colaboración con el Creador ${ }^{21}$. En La Pálida, este personaje responde rotundamente a un sacerdote: «Con la teoría de la existencia del alma no se explican ustedes los actos del hombre, y en cambio se aclaran y explican perfectamente con la positiva e indudable existencia de la materia. La bestia humana, eso es lo evidente, no hay que darle vueltas» ${ }^{22}$.

20 Iris M. Zavala, Ideología y política en la novela española del siglo XIX, Salamanca, Anaya, 1971, señala cómo López Bago, Ortega Munilla, Trigo, Blasco Ibáñez y Baroja recogen el interés por la vida del bajo mundo que muestran Sue, Ayguals de Izco y continuadores (p. 121). Unas páginas más adelante, partiendo de una novela de folletín, nos dice: «Serán los naturalistas los que vuelvan al mundo marginado de prostitutas, truhanes, degenerados y criminales, impulsados por los avances científicos, el darwinismo y el afán incontrolable de epater el mundo burgués circundante» (p. 175).

21 La Prostituta, p. 76.

22 La Pálida, p. 126. En estas novelas, López Bago hace un prolijo uso de sus conocimientos de medicina, como pone de manifiesto en la descripción de las enfermedades, en el abundante empleo de tecnicismos médicos y en las fórmulas dé los preparados, así como en las descripciones de los aspectos fisiológicos que caracterizan a los personajes y que determinan sus actuaciones. López Bago subtitula todas estas obras «novela médico-social», y pone al frente de todas ellas, como lema, una frase de Claude Bernard: «La moral moderna consiste en buscar las causas de los males sociales, analizándolos y sometiéndolos al experimento.» 
Pero con la tercera novela, La Buscona, se produce un notable cambio, puesto también de relieve por Sawa, quien muestra su preferencia por esta obra. No hay aquí nada truculento ni rebuscado: es una historia de amor entre Rosita Pérez, la «buscona» que había aparecido ya en La Pálida, muchacha perteneciente a la clase media (huérfana de un militar, vive con su madre y un hermano, quienes la explotan sin escrúpulos), y un muchacho más joven que ella, Miguel Loitia, estudiante y aspirante a literato, hijo de un "gobernador de los moderados» cuya carrera política terminó en el sesenta y ocho. Es este personaje, el Sr. Loitia, el más conmovedor de los creados por López Bago; hombre duro y enérgico en el desempeño de su cargo de gobernador civil en cuantas provincias lo ha ejercido, pero tierno y sensible en la intimidad de la familia y de los amigos. Es evidente que el escritor ha querido dotar a sus personajes de una mayor riqueza psicológica que los anteriormente creados, pues, aunque actúan según sus impulsos y están sometidos al determinismo, inevitable en esta escuela, todos ellos se debaten entre sentimientos encontrados: Miguel ama a Rosita y siente hacer sufrir a su padre; éste se resigna a la deshonra que supone ese tipo de relaciones, pero también se enorgullece ante sus amigos y contertulios por los primeros escritos de su hijo, publicados en la prensa; Rosita lucha entre el amor al duque de Tres Estrellas, su amante maduro y protector de su familia, y el que siente por el muchacho. Triunfa este último. Después de la dolorosa prueba que para sus relaciones supone la muerte del Sr. Loitia, los amantes deciden seguir viviendo juntos, y la novela se cierra poéticamente con la imagen de una estatuilla que decora el cuarto de la buscona, un «pilluelo de barro cocido, que levantándose la camisa, su único traje, llevábase el faldón a los ojos y lloraba amargamente» ${ }^{23}$.

Por el mismo camino discurre La Querida, aunque va ennegreciendo las tintas al presentarnos en Miguel un caso de neurosis provocada por la lucha entre el amor que siente por Rosita y el imperioso deseo de fundar un hogar como el de su familia y reproducir la vida de sus progenitores tal y como él la vio en su infancia. La pasión por una mujer decadente, una especie de refinada prostituta de la alta sociedad, exacerba su crisis: necesita casarse con ella para hacerla sufrir y romper con Rosa para destruirla. En un final efectista, su «querida», Rosita, paga a su hermano para que lo asesine.

Sin duda, La Buscona es la mejor novela de la tetralogía, y en el cambio de tono de las dos truculentas novelas anteriores a ésta puede haber influido, según mi parecer, A. Daudet, cuya novela Safo, que

23 La Buscona, p. 241. 
cuenta las relaciones entre una modelo de vida libre y un muchacho más joven que ella, fue traducida por López Bago en $1884^{24}$. Se abandonan por completo en esta novela las peripecias, las historias secundarias y las descripciones de escenas sórdidas y efectistas para poner el interés en la construcción de los caracteres y en el análisis de los sentimientos. Sawa se refiere también a A. Daudet en el texto aquí recogido, aludiendo a un incidente del que haré mención en su lugar.

El texto que a continuación reproduzco - y anoto- viene a ser, en cierto sentido, un antecedente de lo que años más tarde serán los apartados titulados «De mi iconografía», tan abundantes como esenciales en Iluminaciones en la sombra. Iris M. Zavala, en el estudio que precede a su edición, señala la línea literaria y los autores de los que arranca Sawa para la concepción de su obra maestra: Hugo, Rimbaud, Baudelaire, Nerval, Verlaine, Retté, Darío y Gómez Carrillo; pues bien, en su propia obra anterior a 1890 contaba ya con algo semejante, algo que su posterior estancia en París modificaría convenientemente. Sawa parte de una actitud admirativa, reverente, ante el escritor, y lo evoca dándonos una visión subjetiva de él. Hay también un predominio de elementos visuales, en imágenes y comparaciones, así como una utilización de términos pictóricos sugerentes: el «exceso de luz» (es ya, desde su inicio, una iluminación) que percibe al traer a su imaginación la figura del escritor le recuerda «los lienzos de la buena escuela veneciana»; o su idea del arte - naturalista - viene a ser «un claroscuro que no ha podido soñar Rembrandt». Pero, por otro lado, encontramos un tono declamatorio más ampuloso y grandilocuente que en el libro de 1910, junto con un empleo de imágenes de raigambre romántica: la aureola de gloria, el león que ya no ruge, el náufrago..., hasta llegar a párrafos desmesurados, como cuando compara la tinta con el rocío de los prados y el tintero con el cáliz de una flor, etc. Todo ello necesita de la contención aprendida luego en el simbolismo. Más interés tiene esa demostración de su cultura, que se refleja en la mención de escritores, pintores, artistas -cosa que también aparece prolijamente en Iluminaciones-: encontramos los nombres de Balzac, Bécquer, Musset, Zola, Sardou, Byron, Goethe, Heine, Daudet, Claretie; los pintores Rembrandt y Jules Dupré, y el ceremista Palissy; y se evidencia cierta ventaja de los escritores románticos sobre los realistas y naturalistas.

24 Pattison, op. cit., p, 57, cita esta traducción: «Safo, costumbres de París». Traducción de Eduardo López Bago, precedida de una carta del ilustre novelista francés; con un prólogo de Eugenio de Olavarría y Huarte. Madrid, ¿Agustín Jubera?, 1884. 
Pero nos encontramos también ante un texto combativo. El escritor muestra aquí una constante de su carácter: es un decidido antiburgués; desprecia a los hombres de negocios, a los del sentido práctico, e incluso declara mirarlos compasivamente, «como miraríamos compasivamente también un caso de imbecilidad o de raquitismo»; y ataca al gobernador civil de Madrid con frases dignas de los mejores momentos de Max Estrella. Emprende, finalmente, la defensa del naturalismo, pero demanda para esta escuela una rectificación, cuyo modelo estaría en La Buscona: no es únicamente lo sórdido y desagradable lo que constituye la realidad; si el naturalismo aspira a la verdad debe unir lo feo a lo hermoso (lograr ese claroscuro); de lo contrario, no daría una verdad completa. Sorprende comprobar cómo esa concepción del relato naturalista no fue seguida por Sawa en sus obras, tremendas y sórdidas; sin embargo, estas opiniones eran perfectamente sinceras: el culto que el escritor profesa a la belleza -según advertimos en sus palabras - quedará potenciado y adquirirá adecuada expresión a partir de su estancia en París. La lógica evolución hacia su segunda época se percibe ya aquí: los autores por él citados y su ideal de arte explican su rápida conversión al credo simbolista, aunque nunca abjurará de su más profunda y auténtica raíz romántica.

\section{IMPRESIONES DE UN LECTOR}

\section{EDUARDO LOPEZ BAGO}

La silueta literaria de López Bago es, aunque no bien marcada todavía, una de las más enérgicas y más bizarras que conozco. Podrá, quizá, faltarle dibujo, no tener el suficiente realce; pero le sobra color, color temerariamente distribuído, hasta formar la más brillante mancha artística de nuestra moderna generación de noveladores.

Cuando evoco su personalidad literaria para no creer agotados del todo los nuevos ideales estéticos de este desdichadísimo país nuestro (que parece colocado a más distancia del cielo que las demás naciones de Europa, según las mayores desventuras que incesantemente lo afligen), hay veces en que tengo materialmente que cerrar los ojos, lastimados por exceso de luz, como me ocurre contemplando los lienzos de la buena escuela veneciana. 
López Bago es el temperamento más heroico de la época, y también el más convencido. Aquellos Amores suyos ${ }^{1}$, publicados hace ya una porción de tiempo, cuando su autor apenas contaba veintidós años, Amores que, aunque predominaba en ellos la nota psicológica sobre la fisiológica, son, en su gran síntesis, un estudio rudo e inexorable del corazón humano, arrancado con valentía del pecho del hombre, y puesto así, palpitante y goteando sangre, ante los ojos del lector, eran, y en ese sentido debió inspirarse la crítica que no es acéfala para juzgarlos, eran más que una realidad, una brillante, una brillantísima promesa de más altas y más radicales empresas. El escándalo que produjo el libro fue enorme: se llamaba atrevido al autor, como si el atrevimiento no fuera un deber del pensador y del soldado, y se le amagaba con echarlo a la policía como se echaban perros a las bestias feroces en los espectáculos bárbaros; pero la chusma policíaca se quedó con las ganas, bostezante y famélica, a pesar de los alaridos salvajes del clero y de los anatemas rabiosos que tiraron contra la bella y soñadora cabeza del joven combatiente, sin conseguir herirla.

Y cuando los hombres esos del sentido práctico, del buen sentido, los hombres de negocios, consiguieron volver a encauzar las actividades anímicas del país hacia la compra y venta del chocolate y los garbanzos, todos nosotros, los que no somos prácticos, y nos honramos mucho en no serlo, y miramos compasivamente a los que lo son, como miraríamos compasivamente también un caso de imbecilidad o de raquitismo; nosotros, los que no somos prácticos, convinimos en que López Bago había desarrollado vientos de progreso en la nación, haciéndola ocuparse tres días seguidos de un libro que no era una tarifa de comercio ni una galería biográfica de toreros ilustres, y que en ese sentido había merecido bien de la patria, $\mathrm{y}$, lo que vale más que eso para los que no nos conmovemos mucho con la idea de patria, bien de la civilización y bien de la cultura humana...

Pasó tiempo; yo era de los treinta o cuarenta mil españoles que se habían aprendido de memoria el nombre de López Bago, porque presentían la aureola de gloria rodeando el nombre del desconocido... - una hermosa aureola que casi siempre hace sangrar la frente del que la lleva...-. El pequeño león ya no rugía; había que declararlo rendido: ya no se revolvía frenéticamente de un extremo a otro de la reali-

1 Los Amores, Sevilla, 1876. Pattison, op. cit., p. 136, recoge la opinión que José Ortega Munilla expresó en El Parlamento, el 27 de enero de 1877; al ilustre periodista y luego novelista naturalista, esta obra le pareció una «novela realista y peligrosamente provocativa». 
dad, ni llenaba el espacio literario con sus alaridos, ni amenazaba a la sociedad con la exposición de las miserias y vicios que la degradan, que la enervan... ¿Lo había descorazonado la primera batalla? ¿Era un náufrago más de los que la civilización arroja, después de ahogarlos, a la orilla, para abandonarlos al análisis hondo y corrosivo del gusano, el último enemigo del hombre...? ¡Ay de la juventud que desanda el camino, que vuelve la espalda a la pelea, que teme el peligro y abandona los puntos de vanguardia al enemigo, a los viejos que tienen la pretensión de continuar siendo jóvenes! ¡Esa juventud cobarde... merecería una maldición, enorme como el mundo, eterna como la creación! ¡Una maldición que no acabara nunca!

No era eso: yo no conocía a López Bago, y por ello lo calumniaba, creyéndolo cobarde; es que entonces, en aquella época de pasividad aparente, López Bago se peleaba con la desgracia, luchaba desesperadamente con el infortunio, y jay! la victoria no se decidía por el hombre; el hombre forcejeaba desde el suelo con los últimos alientos de la desesperación, lleno de fe y de coraje, pero también de heridas y casi desangrado, sin poder conseguir otra cosa que la prolongación de su vida, esto es, la prolongación de su agonía... Como todos los grandes artistas, como Balzac, como Bécquer, como Musset, como Zola, como Sardou $^{2}$, López Bago ha tenido una iniciación dolorosa, iba a decir sangrienta, en la literatura. Ha sufrido, se ha visto negado, iha debido llorar!... ¡Esas lágrimas del pensador, que son lágrimas reconcentradas de una porción de generaciones de mártires! Salió romántico de la lucha con el destino, y escribió La confesión de un escéptico ${ }^{3}$, una hermosísima página, que parece, por su frescura y por sus cambiantes, escrita, no con tinta, esta horrible tinta negra que tantas infamias comete, que ayuda a cometer tantas infamias, sino con el rocío de los campos y sirviéndole de tintero el cáliz delicado de una de esas hermosas flores primaverales, que, a semejanza de ciertas grandes almas, sólo abren sus pétalos a la hora más pura, más silenciosa de la mañana, como para aspirar con mayor éxtasis, con mayor devoción, $y$, ¿por qué

2 La visión de Sawa es encomiástica en exceso, pues lo sitúa a la altura de los grandes creadores decimonónicos. Los nombres que aparecen citados revelan esa mezcla del romanticismo y naturalismo repetidamente aludida, pero el tono de este párrafo nos lleva a destacar su raiz romántica.

3 Obra desconocida. No aparece recogida en ninguna de las bibliografías existentes de López Bago: ni en el libro de Ferreras (cit.), ni en el Ensayo de un Diccionario... de F. C. Sainz de Robles (cit.), ni tampoco en el Manual del librero hispano-americano de Antonio Palau (Barcelona, 1948-1977). Es muy posible que se trate de un artículo periodístico. 

amor cósmico.

Fué periodista político, esclavo sin derecho a la queja, en $E l$ Parlamento ${ }^{4}$, un periódico que no ha debido morir nunca, y periodista literario en La Revista Contemporánea ${ }^{5}$, una de las publicaciones científicas que más honran a España. Su tradición periodística es brillante y justa. Tiene hasta leyenda. López Bago era considerado entonces, entre los iniciados de las redacciones, como uno de los selectos periodistas de la nación.

Yo lo conocí algún tiempo después en La Reforma, periódico que no tenía otro defecto que el de defender la política, bizantina entonces, y ahora risible, del general López Domínguez ${ }^{6}$. Y cuando La Reforma desapareció de la arena, otra nueva inmersión de López Bago en la

4 Además de los periódicos aquí mencionados, sabemos, por F. C. Sainz de Robles (op. cit.), que también colaboró en La Ilustración Española y Americana y La Familia. Walter T. Pattison, op. cit., rescata textos de López Bago de las páginas de El Progreso y de La Ilustración Militar. Pero en el primer párrafo del apéndice de La Pálida (publicada en enero de 1885) dice el autor: «Yo soy uno de los pocos españoles que vivimos en Madrid sin publicar un periódico. Esto no quiere decir que me encuentre sin pecado. He sido periodista hasta que por voluntad y propósito decidido dejé de pertenecer al periodismo, consagrándome por completo a las tareas literarias: vivo, pues, publicando mis libros, escribiéndolos con el mayor esmero que se me alcanza, y cobro la subvención que me paga el público que los compra» (p. 261).

5 Revista quincenal, cuyo primer número vio la luz el 15 de diciembre de 1875 y desapareció en el mes de junio de 1907. Su director y propietario fue José de Cárdenas. En esta publicación se encuentra la primera traducción de Zola al castellano: el cuento «El ataque del molino», el 30 de junio de 1879. (Vide W. T. Pattison, op. cit., p. 51).

6 El general D. José López Domínguez, sobrino del general Serrano, estuvo afiliado a la Unión Liberal. Tras la Restauración, ingresó en el Partido Liberal de Sagasta y fue partidario de implantar la Constitución de 1869; al aceptar los seguidores de Sagasta la Constitución de 1876, López Domínguez siguió a Serrano en la organización de la izquierda dinástica, pues consideraba insuficiente dicha Constitución y pedían su reforma. En 1883 ocupó durante tres meses la cartera de la Guerra bajo la presidencia de Posada Herrera, sin poder cumplir sus propósitos. Fundó luego, con Romero Robledo, el Partido Reformista, en cuyo programa figuraban el jurado, el sufragio universal y la reforma constitucional. Cuando las Cortes votaron las dos primeras leyes, acató la jefatura de Sagasta y fue de nuevo ministro de la Guerra en 1892. El citado periódico La Reforma debió de ser el órgano de expresión de dicho Partido Reformista, pero no he podido localizar su existencia; pues no aparece citado ni en el Catálogo de las Publicaciones periodicas madrileñas existentes en la Hemeroteca Municipal de Madrid (1661-1930), Madrid, Artes Gráficas Municipales, 1933, ni en Antonio Asenjo, La Prensa Madrileña a través de los siglos (Apuntes para su historia desde el año de 1661 al de 1925), Madrid, 1933; ni tampoco en el Manual... de A. Palau. La colaboración de López Bago para el citado periódico debió de efectuarse entre 1883 y 1884. 
sombra; luego supe que se preparaba a escribir su novela política $E l$ Periodista ${ }^{7}$.

Lo vi por la calle cuatro o cinco veces, y nunca me atreví a detenerlo, porque hubiera creído hacerle mala obra: un hombre que va por el arroyo en vez de por la acera, con la cabeza baja y pensativo, las manos cruzadas a la espalda, andando apresuradamente y moviendo los labios como quien habla con una desesperación o con un pensamiento rebelde, tiene derecho a que no se le interrumpa y hasta a que se le abra paso: puede ser funesta la imprudencia de despertar a uno de esos sonámbulos que pasean por la calle sus legiones de ideas.

Elaboraba La Prostituta y La Pálida ${ }^{8}$, y parecía como trastornado por los éxtasis de la concepción. Todas las mujeres que sean madres comprenderán esto mejor que sus esposos y sus hijos educados en los institutos.

Poco tiempo depués, un gran estruendo en las librerías y en las Academias, las opiniones mojigatas asustadas, las hipocresías al uso llenas de indignación, la gente de letras vomitando bilis hasta por los ojos, me apercibieron - a mí, que vivo tan retirado de todo ese odioso mundo externo- me apercibieron de que López Bago daba otra vez la batalla en las calles: la guerra civil de las ideas.

Pero esta vez con más arrogancia que en Los Amores, declarándose a sí propio protestante, retirándose de las otras tiendas, como si adivinara en ellas la peste, rechazando para sus teorías literarias el Derecho de gentes, amenazando con la guerra sin cuartel y contestando como Palafox a sus sitiadores: «Después de la guerra del cañón, la del cuchillo. ${ }^{9}$

7 El Periodista. Novela política, Madrid, 1884. José Carlos Mainer, «José López Pinillos en sus dramas rurales», en Literatura y pequeña-burguesía en España (Notas 1890-1950), Madrid, Edicusa, 1972, nos dice que en esta novela Romero Robledo quedó «estigmatizado para la posteridad como el personaje Campuzano» (p. 90).

8 Sawa parece indicar que las dos novelas fueron concebidas juntamente, lo que puede quedar corroborado por la proximidad entre sus fechas de publicación.

9 Conocemos la existencia de frases similares pronunciadas por el general Palafox durante los sitios de Zaragoza; asi, la respuesta a una lacónica proposición de Verdier, «Paz y capitulación», fue igualmente lacónica: «Guerra y cuchillo». La frase citada por Sawa pudiera ser una modificación de la citada respuesta. Galdós, en Zaragoza, cita otra respuesta al mariscal Lannes: «La conquista de esta ciudad hará mucho honor al señor Mariscal si la ganase a cuerpo descubierto, no con bombas y granadas, que sólo aterran a los cobardes» (Episodios Nacionales, vol. II, Eds. Urbión, S. A., Madrid, 1976, p. 535). 


\section{¿Qué pánico en las filas nerviosas del romanticismo!}

Hasta el gobierno se ha creído en el caso de formular su opinión literaria por medio de uno de sus dependientes, del gobernador civil de Madrid.

López Bago, en el apéndice de La Buscona, califica a D. Raimundo Fernández y Villaverde y García del Rivero, etc., de romántico, no pudiéndose explicar de otro modo la saña con que persigue a sus libros; como si un hombre de la cultura literaria de Fernández y Villaverde y García del Rivero ${ }^{10}$, etc., pudiera ser ni romántico, ni clásico, ni nada, sino gobernador -así lo llaman- de los conservadores. ¿Qué ha de entender de literatura, ni de arte, ni de nada, el autor de ese enrevesadísimo bando pegado en las esquinas a raíz de los motines escolares, que obligó a El Liberal a volver por los fueros ultrajados, desconocidos, negados, no ya del sentido común, que eso es poco, sino hasta de las generalidades más simplicísimas y más elementales de la gramática, de las gramáticas esas para uso de la infancia? ¡Ah! ¡Ese mandarín soberbio, que quiere someter al código la inspiración, decirle al pensamiento: «hasta aquí has de llegar»; reglamentar el arte, dar órdenes a la belleza - iél, Villaverde! - decretar moral desde su despacho y tratar, no ya a las teorías, sino a las opiniones literarias como si fueran verduleras o estudiantes, a sablazos y amenazas, y a quien se le antojan los dedos huéspedes! ${ }^{11}$.

Ha sido un auxiliar poderoso del éxito de La Prostitutá; sus censuras, redactadas en ese empalagoso estilo administrativo, propiedad real y efectiva de los hombres que tienen más vientre que cerebro, han excitado potentísimamente a la venta del libro; si yo fuera López Bago, escribiría a ese gobernador dándole gracias por sus malquerencias y sus hostilidades... Y de ser, o más humano, o más acomodaticio, o más flexible el temperamento social del autor de La Buscona, yo creería que estaba de acuerdo con Villaverde para conseguir lo que ya ha conseguido: vivir fieramente de la renta que le dan sus libros ${ }^{12}$.

10 López Bago, en sus apéndices, lo cita siempre como Villaverde, y fue el autor de las denuncias que recayeron sobre La Prostituta y La Pálida. Fue Gobernador civil de Madrid desde marzo de 1884, sucediendo al conde de Toreno, hasta julio de 1885 en que ocupó la cartera de Gobernación.

11 El motín de estudiantes, severamente castigado, tuvo lugar el 19 de noviembre de 1884. Con la misma energía actuó en otros tres motines que sucedieron a continuación: uno de cigarreras, otro de enfermas del Hospital de San Juan de Dios y otro de vendedoras del mercado de la Plaza de la Cebada, al que alude Sawa en el texto.

12 A esto se refiere también López Bago en el apéndice de El Cura; en p. 280: «mien- 
Apareció La Prostituta, en seguida La Pálida, luego La Buscona, las tres fases de la victoria: primero las hostilidades, luego la jornada, y por último la gloria. Es de esta última de la que quiero principalmente ocuparme; de La Buscona: de la gloria.

López Bago remata su sombrío estudio de la prostitución con una gran aurora, con una imponente explosión de luces y colores, quizá inspirándose en ideas de competencia, de justísimo resentimiento literario y hasta personal con Monsieur Alphonse Daudet, el gran colorista de Francia ${ }^{13}$. La Prostituta y La Pálida son obras implacables, sin nervios y sin entrañas, inexorables, en que el autor se oculta por completo para que sea la realidad sola, pero la realidad más antipática, más odiosa, la realidad que mata al padre y deja a los hijos huérfanos, la realidad que parece cómplice de la infamia, quien hable en todas las páginas, y quien se agite, atormentadora, cobarde, en toda la acción, en todo el argumento del libro.

Y resulta feo. Porque esa sociedad que estudia López Bago en $L a$ Prostituta y La Pálida es fea, esencialmente fea, monstruosa, y huele más al pus y a los desinfectantes de las salas clínicas que al aroma de los campos y que al perfume indistinto de la verdadera belleza.

iAh! El crimen es realidad; la navaja goteando sangre es realidad también; la madre que vende a su hija, el esposo que vende a su mujer, el pensador que vende a su conciencia, las ansias del borracho, los ayes del sifilítico, las agudas estridencias de la virginidad desgarrada, la imbecilidad del que hereda de sus padres malos humores, una complexión raquítica y anemia en la sangre; el hombre que promete, la mujer que

tras que la novela bonita alcanza el mediocre éxito de librería de que ya hice mención, la novela fea, con toda la fealdad de La Prostituta, agota sus ediciones rápidamente».

13 Ya mencionamos la influencia de Safo sobre La Buscona; pero existe también una oscura historia en torno a la carta de A. Daudet que aparece en la traducción de López Bago; a esto se debe de referir Sawa. Pío Baroja (loc. cit.) nos dice en sus Memorias sobre López Bago: «Era un hombre sin escrúpulos. Puso a una novela suya un prólogo falso de Alfonso Daudet, dándose unos bombos terribles a sí mismo. En no sé qué libro francés he leído la protesta de Daudet sobre la atribución de la paternidad de ese prólogo.» En el apéndice a La Buscona, escribe: «Otra cuestión que demuestra las armas a que apela en España la rivalidad de profesión para combatir al que logra vivir de su trabajo y consigue que la venta de sus libros le produzca lo suficiente para atender a las necesidades de su familia, es la carta inserta en mi traducción de Safo, carta que ha resultado ser falsa, y que el editor de esta traducción, y el librero, D. Fernando Fe, saben perfectamente que ha sido un engaño, que no me reportaba ningún beneficio, y del cual no ha sido, en realidad, tan víctima el Sr. Daudet como yo.». Pero no logramos saber nada más. 
fía; el temperamẹnto sexual, priápico, que se retuerce desesperedamente como si estuviese encadenado, y el temperemento linfático, pasivo, que se entrega, que se rinde con facilidad, como si estuviera independiente del cerebro; la sangre viciosa, emporcada, sucia, miserable, que arroja al cerebro, a toda la masa encefálica, cuanta porquería arrastra consigo; vicio, crimen, suciedad, miseria. ¡Cualquiera!, fulano, zutano, yo que digo esto, el vecino de enfrente, ese que quema la cama de su madre para calentar los pies de su querida; ese otro Palissy de la miseria ${ }^{14}$, que quema sus muebles para calentar el puchero de dos reales que ha llevado de la taberna de la esquina; todo esto, ¿no es realidad también? Pero también es realidad la nube, las gasas de vapor que se metamorfosean en la atmósfera marcando sobre fondo azul dibujos fantásticos; la virgen que se resiste asustada de las brutalidades de la materia; fulano y zutana que se aman a pesar de la igualdad de sus temperamentos; la naturaleza, toda la naturaleza bruta, tan opulenta, tan espléndida de perfecciones comø sueñan a Dios las criaturas que tienen la fortuna de creer en Él; el aire embalsamado de los campos; la ilusión rosada o color de cielo meridional de los amantes de quince años; el amor, el vino bebido sin exceso, una buena comida, y la apoteosis de la dicha humana; una mujer joven y espiritual que os diga a gritos después de las adorables confidencias al oído: «Yo te amo por esta noche y por siempre.» ¡Oh! Eso es también realidad y vale la pena de que séa descrita por todos los fotógrafos de la escuela naturalista.

- ¡Le document humain!»- El documento humano ies 'la monstruosidad? Entonces no hay ningún artista en la tierra, ningún amante de la belleza. Todos deben desertar de ella, matarse, suicidarse, antes de que la horrible muerte los asesine a traición por la espalda.

El documento humano no es lo feo, no es sólo lo feo; es también lo bello, lo hermoso. ¿A qué copiar siempre lo feo? ¿Es, por ventura, el fin del arte la negación?

¡Ah! ¡En Francia se equivocan, como se equivocan en España! La realidad no es lo feo. Es lo feo y lo bonito combinados. A veces lo bonito sólo. Lo feo sólo, la nota negra dominándolo todo, el color negro siempre, eso sólo se ve en los carboneros los días de trabajo; los domingos se lavan la cara, se visten de limpio y van a El Ramillete a bailar con sus paisanas; y son morenos, rubios, sonrosados, pálidos. Hombres.

14 Bernardo Palissy, ceramista francés del siglo XVI. En su deseo obsesivo de conseguir un tipo especial de cerámica, Palissy trabajó incansablemente y sufrió la más dura pobreza. Tanto es así que para mantener el fuego de sus hornos tuvo que quemar sus muebles y aún el pavimento de madera de su casa. Sawa traza paralelos actuales, con esa oscura realidad por él observadà. 
El dilema, lo positivo y lo negativo, la tesis y la antítesis, el anverso y el reverso. Ese es el arte. Ni el color blanco, ni el color negro sólo. El blanco y el negro combinados hasta la hermosura absoluta. Un claroscuro que no ha podido soñar Rembrandt.

Por eso prefiero La Buscona a su madre y a su abuela. Porque veo en ella una solución admirable. Es verdad y belleza: vivante et moderne al mismo tiempo, como debe ser el arte a la altura del progreso que hemos llegado.

Parece como si López Bago hubiera sido testigo de aquel interesantísimo diálogo artístico entre Jules Dupré, el eminente paisajista, y su primo Claretie, el hermoso cronista de Le Temps. «N'oublie jamais, decía el pintor al novelista, que pour qu'e une oeuvre d'art soit bonne, il faut le traiter comme Dieu a traité ses arbres; les racines dans la terre et la cime dans le ciel» ${ }^{15}$. Así ocurre con ese libro que me cuesta trabajo llamar La Buscona: que tiene raíces en la tierra y la cima en el cielo.

La protagonista, Rosita Pérez, una ficción literaria de López Bago, es una mujer a la que yo he saludado, y aun algo más que eso, siempre que la he visto por la calle o que la he encontrado en su casa. Miguel Loitia, su amante, tiene todas las sensibilidades y todos los movimientos de la realidad: se mueve porque está formado de músculos y sangre. $\mathrm{Su}$ autor sólo dice de él que es joven. Huelga la declaración. Los que somos jóvenes y los que lo han sido ven la juventud de Miguel Loitia en sus actos, como se ve la descomposición y la recomposición incesante de los mundos en los rayos solares. El padre del amante, el gobernador de los moderados, es la figura más simpática, más bien dibujada, más llena de color y también más movida de la obra. Creo ciegamente en la inmortalidad de esa figura. Es verdadera y humana. No le falta más que el soplo divino para que ande, $y$ hable, y sienta, y ame, y pueda ejercer el despotismo a nombre del conde de San Luis, su amigo, y tomar café en el Suizo en la mesa de los padres, y recitar de memoria los artículos que publicó su hijo en el periódico político a cuya redacción pertenece...

Estoy tan enamorado de la obra que no acabaría nunca de hablar de ella. Por todas sus páginas, absolutamente por todas, se sienten los vagos estrecimientos de la vida que circula. Es un libro animado al cual

15 Jules Dupré (1811-1889). Asensio Arnaldo Claretie, n. en 1840, fue un escritor muy fecundo: periodista, dramaturgo, novelista, crítico e historiador. Publicó en Le Temps durante los años 1881-1885 una serie de artículos bajo el título de $L a$ vie a Paris que tuvo un enorme éxito, siendo recogidos en un libro con el mismo título. 
no le falta más que fisonomía humana, para que sus personajes puedan sentarse con nosotros a la mesa. ¡Y qué buen amigo que sería yo entonces del Sr. Loitia, el gobernador de los moderados, y cómo sabría consolarlo de los extravíos naturalísimos del hijo, citándole una porción de nombres hermosos: Byron, Goethe, Musset, Heine, tan colosales amando como pensando, para probarle que los besos apasionados de una mujer, aunque se llame Rosita Pérez o Nana, que es nombre más espantoso, no chupan ni dignidad ni talento, sino pesares y melancolías de esas que forman grietas en el cuerpo por donde la vida pueda escaparse fácilmente a la primer intimación de la muerte!

Un abrazo entusiasta al heroico campeón del naturalismo radical en España.

ALEJANDRO SAWA. 